Gut, 1988, 29, 1229-1235

\title{
Employment problems and prospects for patients with inflammatory bowel disease
}

\author{
R J WYKE, F C EDWARDS,* AND R N ALLAN \\ From the Gastroenterology Unit, General Hospital, Birmingham and the Medical Division, Health and Safety \\ Executive, Merseyside
}

SUMMARY A random sample of 170 patients ( 88 men) with chronic inflammatory bowel disease (75 ulcerative colitis) were first interviewed in 1978 about their employment status, problems at work, and influence of surgery. Surgery had been carried out on 120 and 53 had an ileostomy. After six years $144(92 \%)$ of the 156 survivors replied to a follow up postal questionnaire. Of the initial sample, $122(72 \%)$ were working and there were only three (1\%) registered unemployed. After six years a similar proportion were working and only seven $(5 \%)$ were unemployed. Continuity of employment was good with $57 \%$ in the same job. Changes in work because of health had been made by 72 patients mainly caused by bowel disease. After surgery $10 \%$ completely changed and $22 \%$ modified their work while a few had to retrain or retire. Panproctocolectomy and ileostomy resulted in more changes and longer time off work after surgery than colectomy and ileorectal anastomosis, with $35 \%$ and $17 \%$ respectively off work after one year. Problems at work, in particular general malaise and arthritis were experienced by $34(28 \%)$ patients. Fewer problems were experienced by patients with a stoma who also had less sickness absence than those without a stoma. Colleagues and employers were usually supportive although some patients encountered discrimination especially those with a stoma or working in the food industry. Few patients had been counselled on their work. In general employment prospects and time off work were good and employers should be encouraged to take an optimistic and supportive role. Doctors should consider that convalescence after surgery may be longer than they perceive and must provide better counselling for patients.

The objective of surgical and medical management of patients with inflammatory bowel disease are to minimise morbidity and restore the individual to good health so that they can return to work. There have been few detailed studies, however, on the impact of chronic inflammatory bowel disease and treatment on employment. Two surveys of patients with Crohn's disease and another of patients with ulcerative colitis have shown that between 65 and $90 \%$ respectively were 'working' or 'fully employed'. ${ }^{1-3}$ Similarly the formation of an ileostomy, as part of panproctocolectomy, has been shown to be followed by resumption of work in 85 to $95 \%$ of patients but in some series housewives were included as 'employed' ${ }^{46}$ More detailed information

Address for correspondence: Dr R N Allan, Gastroenterology Unit, General Hospital, Steelhouse Lane, Birmingham B4 6NH.

Received for publication 25 April 1988.

*Now retired on patients work and associated problems have not been reported. This survey examines the employment status and the associated problems particularly in respect of surgical treatment among patients with chronic inflammatory bowel disease. The longterm outcome has also been evaluated in a group of patients who were interviewed and then reviewed six years later.

\section{Methods}

PATIENTS

A random sample of patients with inflammatory bowel disease under review at the General Hospital, Birmingham, were assessed between March 1978 and April 1979, by one observer (FGE) using an interview and administered questionnaire. This group were reassessed in 1985 by postal questionnaire. The data collected in these two surveys are summarised in Table 1. 
Table 1 Data collected in the two surveys

1 Age, sex, type, and site of disease and surgery.

2 Employment status.

3 Type of work.

4 Continuity of employment (influence of health and surgery on work).

5 Sickness absence as a result of inflammatory bowel disease and health in preceding year.

6 Time off work after surgery.

7 Patients attitude to range of occupation (influence of stoma).

8 Promotion or loss of seniority.

9 Special facilities at work.

10 Advice about work received by patients.

11 Attitude of colleagues and employers.

Table 2 Details of patients studied

\begin{tabular}{|c|c|c|c|c|}
\hline & \multicolumn{2}{|c|}{ Initial survey (1978/1979) } & \multicolumn{2}{|c|}{ Follow up survey (1985) } \\
\hline & $\begin{array}{l}\text { Patients } \\
\text { (n) }\end{array}$ & $\begin{array}{l}\text { Age (mean } \\
(S D))\end{array}$ & $\begin{array}{l}\text { Patients } \\
\text { (n) }\end{array}$ & $\begin{array}{l}\text { Age (mean } \\
(S D))\end{array}$ \\
\hline All patients & 170 & $43(13)$ & 144 & $48(12)$ \\
\hline Men & 88 & $42(14)$ & 73 & $46(12)$ \\
\hline Women & 82 & $44(13)$ & 71 & $50(12)$ \\
\hline Ulcerative colitis & 75 & $\left.46(14)\right|_{*}$ & 61 & $51(12))_{+}$ \\
\hline Crohn's disease & 95 & $40(12)\}^{*}$ & 83 & $46(11)\}^{\dagger}$ \\
\hline
\end{tabular}

${ }^{*} \mathrm{p}<0.01$ (t test) $; \mathrm{tp}<0.05$.

One hundred and seventy patients were surveyed initially. Fourteen died and 12 were lost to follow up, so that 144 were available for reassessment in 1985 (Table 2). The outcome was similar for patients with ulcerative colitis and Crohn's disease so that they are considered as one group except where important differences emerge. One hundred and twenty patients had undergone surgical treatment at the time of the initial survey (carried out since 1954 with more than half after 1970). Eleven other patients underwent surgery during follow up and in all there were 65 whose treatment included ileostomy (Table 3 ).

\section{Results}

DISTRIBUTION OF SOCIAL CLASS

There was a predominance of social class III, nonmanual $(35 \%)$ but almost equal proportions of classes II, III manual, and IV $(21,18$, and $16 \%$ respectively) and small numbers of class I and $\mathrm{V}$ (7 and $3 \%$ respectively). Social class III non-manual was more common among the patients than the West Midlands population (35 and $20 \%$ respectively) and class II manual less icommon (18 and $27 \%$ respectively). The sample size is too small for meaningful comparison.

EMPLOYMENT STATUS (TABLE 4)

One hundred and twenty two (72\%) patients in the
Table 3 Surgical status and follow up of patients with inflammatory bowel disease

\begin{tabular}{|c|c|c|c|c|}
\hline Type of operation & $\begin{array}{l}\text { Initial } \\
\text { survey }\end{array}$ & $\begin{array}{l}\text { Follow up } \\
\text { survey }\end{array}$ & Lost & Died \\
\hline None & 50 & 29 & 5 & 5 \\
\hline $\begin{array}{l}\text { Colectomy and ileorectal } \\
\text { anastomosis }\end{array}$ & 25 & 21 & 2 & 1 \\
\hline Panproctocolectomy and ileostomy & 53 & 57 & 2 & 5 \\
\hline Colectomy and ileostomy & $5 *$ & 4 & - & - \\
\hline \multicolumn{5}{|l|}{ Segmental resections } \\
\hline $\mathrm{R}$ hemicolectomy $\dagger$ & 30 & 26, & 2 & 3 \\
\hline Terminal & 36 & 32 & 3 & \\
\hline Ileal resection & $6\}^{0}$ & $6\}^{\circ}$ & 1 & \\
\hline Ileostomy & 1 & 1 & - & - \\
\hline Total & 170 & 144 & 12 & 14 \\
\hline Ileostomy present & 63 & 65 & & \\
\hline
\end{tabular}

*1 subtotal colectomy; fileostomy (converted to PPC and ileostomy between 1978 and 1985).

Table 4 Distribution of employment in 1978 and 1985

\begin{tabular}{|c|c|c|c|c|c|c|}
\hline \multirow[b]{2}{*}{ Empoyment status } & \multicolumn{3}{|c|}{ Initial survey } & \multicolumn{3}{|c|}{ Follow up survey } \\
\hline & Men & Women & Total & Men & Women & Total \\
\hline Full time & 58 & 25 & 83 & 50 & 20 & 70 \\
\hline Part time & - & 24 & 24 & 3 & 16 & 19 \\
\hline Selfemployed & 5 & 3 & 8 & 3 & 2 & 5 \\
\hline Sheltered & 1 & - & 1 & - & - & - \\
\hline $\begin{array}{l}\text { Sickness benefit on last } \\
\text { employers' books }\end{array}$ & 2 & - & 2 & - & 1 & 1 \\
\hline Full time education & 3 & 1 & 4 & 1 & - & 1 \\
\hline Housewife & 4 & 24 & 28 & 2 & 22 & 24 \\
\hline $\begin{array}{l}\text { Sickness benefit not on } \\
\text { books of last employer }\end{array}$ & 6 & - & 6 & 3 & 1 & 4 \\
\hline Unemployed & 2 & 1 & 3 & 6 & 1 & 7 \\
\hline Retired & 3 & 8 & 11 & 5 & 8 & 13 \\
\hline Total & 84 & 86 & 170 & 77 & 71 & 144 \\
\hline
\end{tabular}

initial survey were working (including four in full time education). The others were full time 'housewives' (28), retired (11), in receipt of sickness benefit (six) and unemployed (three). The results obtained in 1985 were similar. Unemployment increased from three $(1 \%)$ to seven $(5 \%)$ and the retired group from $11(6 \%)$ to $13(9 \%)$. Only two of the $13(9 \%)$ patients retired because of ill health (arthritis and renal failure secondary to amyloidosis from Crohn's disease).

Continuity and distribution of employment after six years was good, with $57 \%$ in the same job for the same employer. Ten per cent were doing different work for the same employer and $16 \%$ had changed their work and employer. There had been no major changes in the type of work (Registrars General Classification) undertaken by the patients as a whole (Table 5). 
CHANGES IN WORK CAUSED BY ILL HEALTH Changes in work as a result of ill health were common. Seventy two patients changed some aspect

Table 5 Type of work according to Registrars General Classification, in initial and followup surveys compared with regional distribution of employment

\begin{tabular}{|c|c|c|c|}
\hline & $\begin{array}{l}\text { Initial } \\
\text { survey } \\
\%\end{array}$ & $\begin{array}{l}\text { Follow up } \\
\text { survey } \\
\%\end{array}$ & $\begin{array}{l}\text { Regional } \\
\text { distribution* } \\
\%\end{array}$ \\
\hline Farmers, foresters, and fishermen & 1 & 2 & 1 \\
\hline Electrical and electronics workers & 3 & 2 & 2 \\
\hline $\begin{array}{l}\text { Engineering and allied trades } \\
\text { workers }\end{array}$ & 12 & 9 & 17 \\
\hline Food, drink, and tobacco & 2 & - & $0 \cdot 3$ \\
\hline Paper and printing workers & 3 & 4 & $0 \cdot 4$ \\
\hline Makers of other products & 1 & 1 & $1 \cdot 5$ \\
\hline Painters and decorators & - & 1 & $1 \cdot 3$ \\
\hline $\begin{array}{l}\text { Drivers of stationary engines, } \\
\text { cranes, etc }\end{array}$ & 1 & - & \\
\hline $\begin{array}{l}\text { Transport and communication } \\
\text { workers }\end{array}$ & 48 & 34 & $6 \cdot 3$ \\
\hline $\begin{array}{l}\text { Warehousemen, storekeepers, } \\
\text { packers and bottlers }\end{array}$ & 3 & 1 & \\
\hline Clerical workers & 30 & 28 & 14 \\
\hline Sales workers & 7 & 10 & $5 \cdot 5$ \\
\hline $\begin{array}{l}\text { Service, sport, and recreation } \\
\text { workers }\end{array}$ & 7 & 7 & 6 \\
\hline Administrators and managers & 8 & 10 & $8 \cdot 6$ \\
\hline $\begin{array}{l}\text { Professional and technical workers } \\
\text { and artists }\end{array}$ & 17 & 20 & $13 \cdot 5$ \\
\hline
\end{tabular}

*Regional distribution derived from OPCS 1981 economic activity of Great Britain.

Table 6 Reasons and type of change of work due to health in 72 patients

\begin{tabular}{llllll}
\hline & \multicolumn{5}{c}{$\begin{array}{l}\text { Modified } \\
\text { Had to }\end{array}$ work of } \\
Reason & $\begin{array}{l}\text { Retired } \\
\text { change }\end{array}$ hours & prematurely & $\begin{array}{l}\text { Lighter } \\
\text { work }\end{array}$ & Total \\
\hline $\begin{array}{l}\text { Inflammatory bowel } \\
\text { disease }\end{array}$ & $30(14)$ & $14(4)$ & $3(2)$ & - & 47 \\
$\begin{array}{l}\text { Surgery } \\
\text { Other illness }\end{array}$ & 7 & $7(4)$ & $3(2)$ & 1 & 18 \\
Total & $5(3)$ & - & 1 & - & 6 \\
\hline
\end{tabular}

Figures in parenthesis represent the number of women. of their work practice. Forty two made a complete change, 21 modified their work or hours and seven took early retirement (Table 6). Six years later 10 further patients had modified or changed their work, one had retrained, four had retired prematurely, and two took voluntary redundancy. The most common reason for these changes was inflammatory bowel disease $(58 \%)$ itself.

\section{CHANGES IN WORK AS A RESULT OF SURGERY}

After surgical treatment $53(44 \%)$ of 120 patients made no changes to their work. Twelve patients $(10 \%)$ made a complete change to their work due to health problems. Twelve and a half per cent modified their work or hours, $1.7 \%$ retrained, $4.2 \%$ took premature retirement, and $3 \cdot 3 \%$ chose lighter work. A further $29(25 \%)$ patients changed work voluntarily unrelated to their health or surgical treatment. Changes were most marked after panproctocolectomy and ileostomy ( $43 \%$ altering some aspect of their work compared with $20 \%$ after colectomy and ileorectal anastomosis $\left.p<0.05 \chi^{2}\right)($ Table 7).

TIME OFF WORK AFTER SURGERY

Data on time off work after surgery were obtained from 87 patients who had undergone surgery more than one year before interview. Patients were absent from work from six weeks to five years (median six months) (Figure). Eleven patients were absent from work for more than one year and seven others never returned. Ill health was responsible for all of those who 'never returned' and three of these had led to retirement. Four of the 11 patients who had been away from work for more than a year had made a voluntary decision not to work, ill health was responsible for four others, while the remainder had reached retirement age, been advised to change work or were retraining. The most common type of ill health in these two groups of patients were arthritis and/or lumbar spondylosis in four and poor general health in five.

Patients who underwent panproctocolectomy and ileostomy tended to be off work longest and included 14 of the 18 who either had been absent for more than

Table 7 Relation of type of most recent major operation to change in employment

\begin{tabular}{|c|c|c|c|c|c|c|c|c|}
\hline Type of Operation & No change & $\begin{array}{l}\text { Had to } \\
\text { change }\end{array}$ & $\begin{array}{l}\text { Modified } \\
\text { work/hours }\end{array}$ & Retrained & $\begin{array}{l}\text { Premature } \\
\text { retirement }\end{array}$ & $\begin{array}{l}\text { Lighter } \\
\text { work }\end{array}$ & $\begin{array}{l}\text { Change not } \\
\text { due to health }\end{array}$ & Total \\
\hline Colectomy + IRA & 11 & 2 & 2 & - & 1 & - & 9 & 25 \\
\hline PPC and ileostomy & 18 & 8 & 6 & 2 & 3 & 4 & 12 & 53 \\
\hline Colectomy and ileostomy & 3 & - & 2 & - & - & - & 1 & 6 \\
\hline Segmental resection & 20 & 2 & 5 & - & 1 & - & 7 & 35 \\
\hline Ileostomy & 1 & - & - & - & - & - & - & 1 \\
\hline $\begin{array}{l}\text { Total } \\
(\%)\end{array}$ & $\begin{array}{l}53 \\
(44 \cdot 1)\end{array}$ & $\begin{array}{l}12 \\
(10 \cdot 0)\end{array}$ & $\begin{array}{l}15 \\
(12 \cdot 5)\end{array}$ & $\begin{array}{l}2 \\
(1 \cdot 7)\end{array}$ & $\begin{array}{l}5 \\
(4 \cdot 2)\end{array}$ & $\begin{array}{l}4 \\
(3 \cdot 3)\end{array}$ & $\begin{array}{l}29 \\
(24 \cdot 2)\end{array}$ & $\begin{array}{l}120 \\
(100)\end{array}$ \\
\hline
\end{tabular}




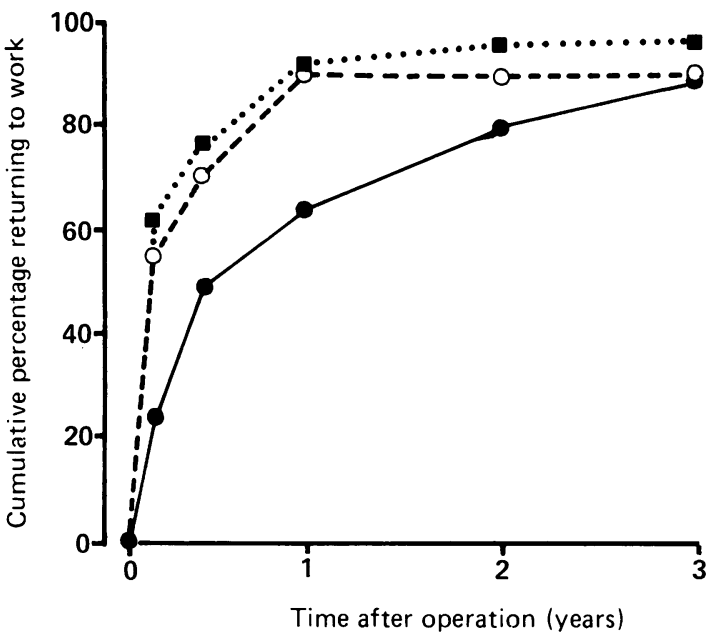

Figure Time taken to return to work by 87 patients after major surgery for inflammatory bowel disease. $\bigcirc--O$ panproctocolectomy and ileostomy $(n=41)$; $X--X$ colectomy and ileorectal anastomosis $(n=20)$;

- - resections of segments of bowel $(n=26)$.

one year or never returned to work. Follow up (1985) found none of the 'never returned' to be working, but four of the 11 'absent from work for more than one year' were working.
SICKNESS ABSENCE

In the year preceding each survey, 58 and $54 \%$ of patients respectively had been at work full time without associated sickness absence (Table 8). Stoma patients lost significantly less time off work than the others, absences in the initial survey were 29 and $48 \%$ respectively $\left(p<0 \cdot 05, \chi^{2}\right)$. Absence of more than one month among ulcerative colitis patients in the follow up period were significantly more common $(\mathrm{p}<105$, $\chi^{2}$ ) than either during the initial period or for patients with Crohn's disease. There was no relation between duration of disease and severity or extent of disease. Sickness absence was attributed to bowel problems in $44 \%$, general malaise $44 \%$, and miscellaneous $12 \%$ including arthritis, pyoderma gangrenosum, depression, and thyrotoxicosis.

PRACTICAL PROBLEMS AT WORK AND THE INFLUENCE OF AN ILEOSTOMY (TABLE 9)

The main problems were general malaise and toilet access. The problems at work, in particular general malaise, increased from 12 to $26 \%$ in the two studies. Problems at work were more common among patients without stomas. Malaise was not related to disease activity or drug therapy and was not associated with absence from work the previous year. Special problems were experienced by those working on production lines, in a restricted environment (out

Table 8 Relation of sickness absence to disease and stoma status in year preceding initial and follow up survey

\begin{tabular}{|c|c|c|c|c|c|c|c|c|c|c|c|c|}
\hline \multirow{3}{*}{$\begin{array}{l}\text { Duration of } \\
\text { disease }\end{array}$} & \multicolumn{6}{|c|}{ Initial survey } & \multicolumn{6}{|c|}{ Follow up survey } \\
\hline & \multicolumn{2}{|l|}{$U C$} & \multicolumn{2}{|c|}{ Crohn's } & \multicolumn{2}{|l|}{ Total } & \multicolumn{2}{|l|}{$U C$} & \multicolumn{2}{|c|}{ Crohn's } & \multicolumn{2}{|l|}{ Total } \\
\hline & Stoma & No stoma & Stoma & No & a Stoma & No stoma & Stoma & No & a Stoma & No stoma & Stoma & No stoma \\
\hline None & 12 & 17 & 17 & 26 & 29 & 43 & 12 & 14 & 18 & 12 & 30 & 26 \\
\hline$<1$ month & 2 & 6 & 4 & 14 & 6 & 20 & 7 & 9 & 3 & 18 & 10 & 27 \\
\hline $2-3$ months & 1 & 3 & 2 & 6 & 3 & 9 & - & 1 & 1 & 5 & 1 & 6 \\
\hline $4-5$ months & - & 1 & - & 5 & - & 6 & - & - & 2 & 1 & 2 & 1 \\
\hline $6-12$ months & 2 & 1 & 1 & 3 & 3 & 4 & - & - & - & 1 & - & 1 \\
\hline Total & 17 & 28 & 24 & 54 & 41 & 82 & 19 & 24 & 24 & 57 & 43 & 61 \\
\hline
\end{tabular}

Table 9 Relation of problems at work to type of disease and stoma stutus

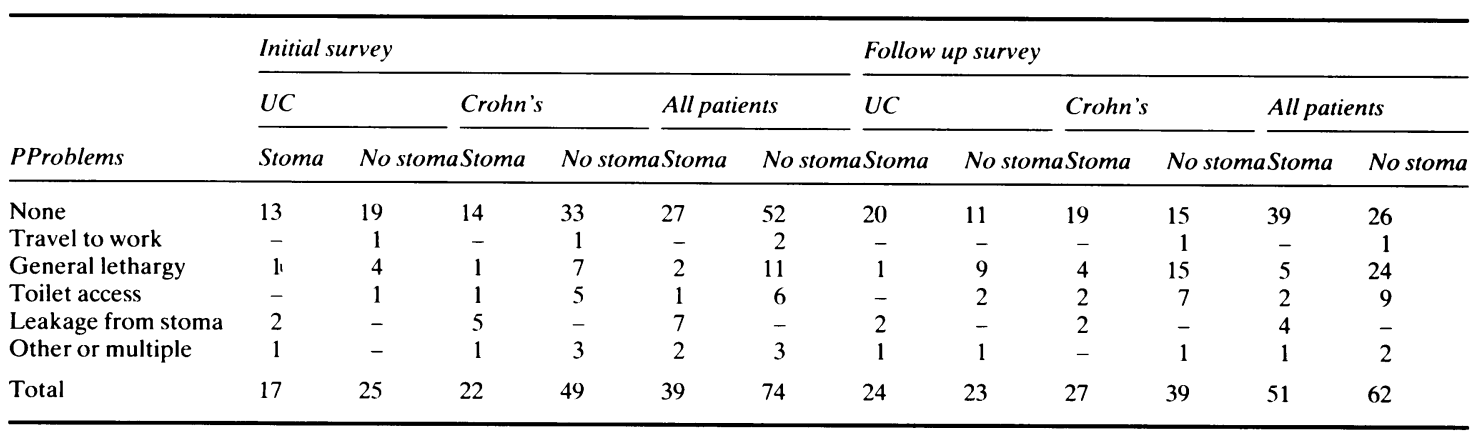


of doors, underground, in special clothing, frequent travelling, or with arthritis). Most patients found toilet facilities at work adequate $(93 \%)$. Hot dirty environments were a particular problem for stoma patients, for whom privacy was also important.

\section{PATIENTS ATTITUDE TO THEIR ILEOSTOMY}

Most patients $(64 \%)$ considered that surgery which included stoma formation had no adverse effect or had actually enabled them to resume work $(11 \%)$ often after prolonged sickness absence. Some $(15 \%)$ changed or modified their work and a few $(8 \%)$ stopped work mainly as a result of arthritis.

\section{PATIENTS ATTITUDE TO RANGE OF THEIR}

OCCUPATION

Most patients $(55 \%)$ considered that their range of occupation was unrestricted $(40 \%)$ or only partly restricted $(40 \%)$. There was major restriction in only $6 \%$. There was no relation between patients attitude and their age, sex or type of surgery.

ATTITUDES OF COLLEAGUES ANDEMPLOYERS The attitude of colleagues was generally 'helpful' $(80 \%)$, neutral $(18 \%)$ with only $2 \%$ unhelpful. Colleagues attitude was unrelated to the presence (77\% helpful) or absence of an ileostomy (82\% helpful).

\section{DISCLOSURE}

Twenty eight patients (19\%) had not informed their employer of their disease of whom 12 had a stoma. Of the 114 patients who had told their employers, $77 \%$ found their attitude to be 'helpful', 19\% neutral, and only $4 \%$ unhelpful.

\section{PROMOTION}

Several patients experienced loss of seniority and/or employment especially after disclosure of their illness or presence of a stoma. Most patients (57\%) felt that surgery had not influenced promotion. Indeed $32 \%$ had eventually been promoted and only $11 \%$ demoted. There was little difference in career prospects for patients with and without a stoma. A stoma was more commonly an adverse feature in Crohn's disease than in ulcerative colitis.

\section{DISCRIMINATION}

Discrimination was uncommon being experienced by seven patients. Three patients were refused work, two in management posts and one in secretarial work who had also been barred from the company's pension scheme. One patient who had lost his job had experienced problems in obtaining work in the food industry and had been forced to take early retirement on health grounds. Another felt that failure to gain promotion was because of possession of a stoma. Ill health during shift work and communication problems with employers and colleagues about leakage from a stoma resulted in two patients losing their jobs.

ADVICE TO PATIENTS ON WORK

Only 16 patients had received advice from either occupational physicians (three), hospital specialists (four), general practitioners (six), or an employer (one). Ten patients modified or changed their work, two women became housewives, one became unemployed and three men became registered disabled or took early redundancy. Three of these patients had been advised that specific work was unsuitable laboratory work, handling of toxic chemicals; sales assistant in a food supermarket, and food handling.

\section{IMPACT ON DOMESTIC ACTIVITY}

Women considered their domestic activities (housework, looking after the family, and social activities) to be unrestricted $(66 \%)$ and those with an ileostomy were less frequently restricted than those without $19 \%$ and $41 \%$ restricted respectively. Only five (6\%) of women were sufficiently incapacitated that they were unable to do their housework and needed some help in preparation of meals. Arthritis was the main reason for this restriction.

\section{Discussion}

Patients in this study were selected at random from a busy specialist clinic which includes a high proportion of secondary referrals and thus many patients had undergone colectomy for extensive disease. Selection of patients from among those attending the clinic tends to include a higher proportion of symptomatic patients than would have occurred had they been drawn at random from the whole series.

The number of unemployed were low in both samples ( 2 and $5 \%$ respectively) a finding in common with a survey from Copenhagen, ${ }^{3}$ and well below the regional average of six and $15.5 \%$ respectively. ${ }^{7}$ Fewer women were working than men perhaps because more women worked in the home, whereas the only real alternative for men was to register as unemployed. Continuity of employment was good with $57 \%$ in the same job for the same employer after six years. Similar findings have been reported for patients with Crohn's disease and for people with an ileostomy. ${ }^{18}$

Health problems resulted in a third of patients modifying their work while a further $14 \%$ changed their work completely or took premature retirement. The changes were generally attributed to the inflammatory bowel disease itself or to the associated 
arthritis. Panproctocolectomy and ileostomy resulted in more work changes than colectomy and ileorectal anastomosis or resections of segments of bowel perhaps because of a genuine influence of stoma formation on employment. Prolonged absence was more common after panproctocolectomy and ileostomy than after colectomy and ileorectal anastomosis or resections of segments of bowel. This difference may partly be because of delayed healing of the perineal wound after panproctocolectomy. Watts et $a l^{4}$ reported incomplete healing of the perineal wound in $25 \%$ of patients six months after panproctocolectomy for ulcerative colitis and others have found similar problems in patients with Crohn's disease. ${ }^{9}$ That $50 \%$ of the surgically treated patients were still off work after one year is, however, disturbing. It was often not clear why patients who felt well had not resumed work, a finding in common with Whates and Irving ${ }^{8}$ who thought that there might no longer be a need for patients to work just to avoid submitting to their disease. The delay may also be because of a reluctance on the part of the medical practitioner to accept responsibility for sanctioning a return to work. The morbidity and time off work after surgery, especially for panproctocolectomy must be considered when counselling patients especially for elective surgery.

Sickness absence in the initial, and follow-up surveys, was low (majority<one month) especially for stoma patients a finding in common with other reports. ${ }^{12}{ }^{10}$ Data from two large work studies suggest that on average men lost 12 days and women 16 days per year. ${ }^{11}{ }^{12}$ Although selfcertification was introduced during the follow up period this has been shown not to result in an increase of duration of sickness absence. Patient numbers in specific occupational groups or within groups of different social class were too small to enable sickness absences to be compared.

Fewer problems at work were encountered by patients with a stoma. Increasing numbers of patients with Crohn's disease but without a stoma, however, experienced problems at work over the study period. General fatigue was the most common problem but this is also a very common complaint of the general population. Toilet access can be a major problem especially for patients with outside work, restricted toilet access or reduced mobility - for example, arthritis or use of protective clothing. To overcome this problem some patients had to modify their work. Two men who had worked as coal miners had to take jobs on the surface after formation of their ileostomy. The patients' assessment of the influence of their stoma on their work was encouraging. Two-thirds considered that there had been no adverse affect while a fifth were able to resume work after long periods of ill health. Although some patients had had to change work, what was more disturbing was that others had experienced problems obtaining or continuing work, a finding in common with other surveys. ${ }^{813}$ It proved easier to continue within the same concern than to seek new work. Employers and colleagues were generally supportive and only a few patients experienced an unhelpful attitude.

The disclosure of a medical condition to an employer can have a varied response. Some patients reported changes in the attitude of employers or potential employers once they learnt of their condition. This was particularly the case for patients working in the food industry. These inconsistencies are difficult to evaluate as there may be other, nonmedical, reasons for the employers actions. We have therefore undertaken a survey of the attitude of occupational physicians to employment of patients with stomas. Preliminary (unpublished) results suggest that inconsistencies do exist especially with respect to food handling and further education of occupational physicians may be valuable in helping them to advise employers on these uncommon cases.

Only a few patients considered that they had failed to obtain promotion or been demoted as a result of possessing a stoma, a finding in common with a survey of the Ileostomy Association. ${ }^{8}$ Such cases are difficult to assess but some do seem to be unfair. Advice on employment had been received by only $10 \%$ of patients usually from their general practitioner or hospital specialist and had resulted in modifications to their work, retirement or registration as disabled. The lack of counselling and appropriate advice to these patients is surprising and doctors are at least in part to blame.

This study has confirmed that patients with inflammatory bowel disease can have good job prospects. Morbidity after surgery, especially after panproctocolectomy, was greater than we expected and must be considered when planning elective surgery. The low level of both sickness absence and problems at work were marked especially for patients with a stoma. Physicians must discuss employment and return to work with the patient and counselling should be sought in difficult cases. Occupational physicians and employers must be encouraged to take a more optimistic outlook of the longterm prospects and good work record of these patients.

\section{References}

1 Gazzard BG, Price HL, Libby GW, Dawson AM. Social toll of Crohn's disease. Br Med J 1978; ii: 1117-9.

2 Sorensen VZ, Olsen BG, Binder V. Life prospects and quality of life in patients with Crohn's disease. Gut 1987; 28: $382-5$. 
3 Hendriksen C, Kreiner S, Binder V. Long term prognosis in ulcerative colitis - based on results from a regional patient group from the county of Copenhagen. Gut 1985; 26: 158-63.

4 Watts J McK, DeDombal FT, Goligher JC. Long term complications and prognosis following major surgery for ulcerative colitis. Br J Surg 1966; 53: 1014-23.

5 Daly DW, Brooke BN. Ileostomy and excision of the large intestine for ulcerative colitis. Lancet 1967; ii: 62-4.

6 Roy PH, Sauer WG, Beahrs OH, Farrow GM. Experience with ileostomies. Evaluation of long term rehabilitation in 497 patients. Am J Surg 1970; 119: 77-86.

7 Department of Employment. Employment Gazette. April 1985; Vol 93 (4) London: HMSO.

8 Whates PD, Irving $M$. Return to work following ileostomy. Br J Surg 1984; 71: 619-22.

9 Scammell BE, Keighley MRB. Delayed perineal healing after proctocolectomy for Crohn's colitis. $\mathrm{Br} \mathrm{J}$ Surg 1986; 73: 150-2.

10 Wilson E. The rehabilitation of patients with an ileostomy established for ulcerative colitis. Med J Aust 1964; 1 : 842-5.

11 Cabinet Office (Management and Personnel Office). Sickness absence. In: Semmence A, ed. The health of the civil service. Civil Service Advisory Service. London: HMSO, 1985: 40-9.

12 Anonymous. Annual report of sickness absence and wastage in the Post Office and National Girobank 19821983. London: Post Office, 1984.

13 Lenneberg E, Rowbotham JL. The ileostomy patient. Illinois USA: Charles Thomas, 1970: 15-64. 


\section{Books}

Manual of nutritional therapeutics. By D H Alpers, E Ray, and W F Stenson. (Pp. 486; illustrated; £9.45.) Boston, Massachusetts: Little, Brown, 1988. This small volume is aimed at health care professionals involved in the clinical management of nutrition. Unlike many textbooks the authors have not restricted themselves to the practise of nutritional support, but clearly outline the pathophysiology underlying specific problems and the theoretical basis for correction of abnormalities. The text is well referenced throughout with sections of suggested reading at the end of each chapter. A chapter on obesity is a welcome addition to the second edition, as this is a subject all too frequently neglected elsewhere. The chapters on enteral and parenteral nutrition contain guidelines on practical techniques, although some of the points relating to enteral feeding seem a little outdated. There seems little point in quoting a paper nine years old, which describes adapting a central venous catheter for small bore feeding, and one suspects this slipped through the net from the first edition. Few clinicians would now support the use of TPN as primary therapy in Crohn's disease or ulcerative colitis. The description of the 'recently available three-in-one TPN infusion technique' emphasises the differences in practice between the USA and Europe, where such a technique has been in regular use for almost a decade. Quibbles apart, this book is a mine of information, and even includes an appendix detailing nutritional analyses of fast foods (UK readers will be dismayed to find no mention of a Wimpy). This book, competitively priced, will be of use to anyone involved in nutritional support, and would be invaluable for those seeking a comprehensive introduction to the subject.

D B A SILK

A practical approach to paediatric gastroenterology. By Joseph Levy. (Pp. 197; illustrated; price not stated.) London: Year Book Medical Publishers Ltd, Chicago, 1988.

This is an interesting book by a second generation paediatric gastroenterologist. Now that paediatric gastroenterology is coming of age the literature is rapidly expanding and this practical book is to be recommended to trainees interested in this subject. Its approach is often synoptic but it is very welcome. This book has the great virtue of being a single author text and as a result has a uniformity of style and a clarity of purpose as well as being very practical. It gives a brief resumé, where appropriate, of basic mechanisms. A useful brief bibliography for each chapter is given to encourage further reading in depth on the topic covered. There are, however, clear differences from British practice as the concepts of cow's milk sensitive enteropathy and cow's milk colitis are not to be found here and the indication for small intestinal biopsy seem largely concerned with coeliac disease. These criticisms really reflect differences in practice across the Atlantic and should not detract from what is a vey useful practical book, albeit written for American rather than British practice. It is a useful introduction to the subject and should encourage the reader to go on to enjoy larger texts with more substance.

J A WALKER-SMITH

\section{Books received}

Clinical progress in nutrition research Edited by $\mathrm{A}$ Sitges-Serra, A Sitges-Creus, and S Schwartz-Riera. (Pp. 282; illustrated; £53.20.) Basel: S Karger, 1988. 1988 Yearbook of diagnostic radiology Edited by D G Bragg. (Pp. 524; illustrated; £35.50.) Chicago: Year Book Medical Publishers, 1988.

New trends in ulcer disease By $F$ Di Mario, $G$ Battaglia, and F Vianello. (Pp. 314; illustrated; 50,000 Lira.) Padua: Piccin Nuova Libraria, 1988.

Retroperitoneum and intestine By K C Suen. (Pp. 214; illustrated; £44.75.) New York: Igaku-Shoin, 1987.

A colour atlas of human anatomy By $\mathrm{R} \mathrm{M} \mathrm{H}$ McMimm and R T Hutchings. (Pp. 358; illustrated; £29.50.) London: Wolfe Medical, 1988.

\section{Correction}

The symbols for the Figure of the article by Wyke, Edwards and Allan (Gut 1988; 29: 1229-35) should have read:

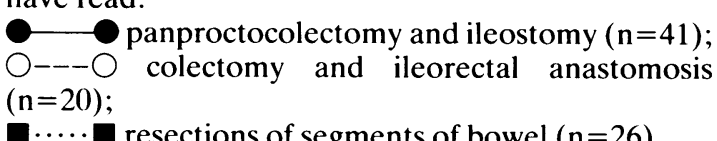

